\title{
DETERMINANTS OF WORLDWIDE SOFTWARE PIRACY LOSSES
}

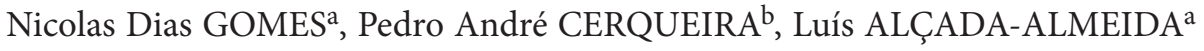 \\ aINESCC, Faculty of Economics, Coimbra University, Coimbra, Portugal \\ ${ }^{b}$ GEMF, Faculty of Economics, Coimbra University, Coimbra, Portugal
}

Received 26 January 2014; accepted 02 May 2015

\begin{abstract}
This paper studies the determinants of software piracy losses along five major macroeconomic dimensions: Technological, Educational, Institutional, Access to Information and Labor force. The study was conducted based on a large dataset available from 1995 to 2010 and comprising 81 countries.

As for the Technological dimension, more patents by residents increases piracy losses while the effect of $R \& D$ is the opposite (decreases piracy losses). In terms of the Educational dimension, the results show that more spending on education increase the piracy losses but, at the same time, more schooling years have the contrary effect. Concerning the Institutional dimension, nations with less corruption have lower piracy levels. Regarding the Access to Information, it seems that access to Internet diminishes the losses while the share of Internet broadband subscriptions has no effect. The results also show that, regarding the Labor dimension, employment in services has a deterrent effect while labor force with higher education and youth unemployment increases piracy losses.
\end{abstract}

Keywords: piracy losses, software piracy, copyright, system GMM.

JEL Classification: C12, C23, C51, L86.

\section{Introduction}

In the past decades we have witnessed a huge development on hardware and software industries. Some examples of these developments are related to operating systems such as "Windows" and "Apple ${ }^{\oplus}$ Macintosh" and their user interfaces. As personal computers became more powerful, an increasing amount of software was developed for a broad array of applications, e.g. those used for music and digital editing.

These developments brought the need to improve the existing software to meet the requirements of consumers. These improvements came at a cost: companies need to engage in continuous research and development $(R \& D)$ efforts to maintain quality and keep up with changes in technology. Investment costs are passed to consumers in the form of a license; the consumer pays to use the software during a certain amount of time or buys a perpetual 
license for that particular software. Investments in software development should be made in parallel with the development of measures for hardware and software protections against piracy. Software has the characteristic of being easily replicated due to the Internet and distributed with virtually any cost associated, as does not have a physical form.

Unfortunately the software protections are often hacked. This happens when the original program protection is bypassed by another program or action performed by hackers. Before the expansion of Internet, only hard copies were available which were easier to track. The exponential growth of Internet speeds led to availability of digital copies, both legal and illegal. Investment that the companies make must incorporate different layers/levels of protection, from development to commercialization. To cover these costs the companies must increase $R \& D$, which increases the initial prices, but these prices sometimes take away potential buyers (Poddar 2005).

Due to the increase importance of the software piracy phenomenon, previous research studied its determinants resorting to the software piracy rates as the dependent variable (Andrés, Goel 2012; Goel, Nelson 2012). However, official publications also report the software piracy losses and up to our knowledge no empirical work conducted an analysis of this variable.

Both piracy rates and losses measure the illicit behavior in a country. In the first case it measures the percentage of software that is being illegally used at a given time, but it omits the importance of the software industry in the economy. We can have countries with low piracy rate and huge losses (e.g. USA) or countries with piracy rates above $90 \%$ but representing little impact on this industry due to the small domestic software markets.

Our contribution to the literature is as follows:

- we will examine what are the determinants of software piracy losses along five dimensions: the technological development, the level of education, the correct functioning of institutions, the availability of information and the structure of the labor force;

- we will use a panel methodology that provides consistent estimates when the dataset is persistent: the System-GMM proposed by Arellano and Bover (1995) and Blundell and Bond (1998) $)^{1}$.

The structure of the paper is the following: Section 1 reviews the empirical literature. Section 2 explains the various dimensions and possible effects, section 3 describes the econometric specification and the results, and the last section concludes.

\section{Literature review}

This section reviews the empirical works that used cross-sectional and/or panel data to explain the software piracy phenomenon using the data provided by the Business Software Alliance (BSA). Some of the studies that use cross sectional data are Marron and Steel (2000), van Kranenburg and Hogenbirk (2005), Banerjee et al. (2005), Andrés (2006b), Goel and Nelson (2009), Andrés and Goel (2011) and Goel and Nelson (2012). Examples

\footnotetext{
${ }^{1}$ Due to data restrictions, previous research used two main methodologies: cross-sectional and/or panel data using the fixed effect (FE) estimator.
} 
of studies that used panel data are: Andrés (2006a), Andrés and Asongu (2013), Asongu (2012), Boyce (2011) and Chen et al. (2010).

The majority of studies find that income, namely Gross Domestic Product (GDP) is negatively related with software piracy (see for instance Marron and Steel (2000) and Andrés (2006a)), which indicates that more income can be devoted to digital content such as software. Also within a country, inequality plays an important role as Andrés (2006b) find that more equal societies are associated with lower software piracy.

Several measures of education were also used to assess its impact on piracy. One of them was the average years of schooling in population with age over 25 years (see Barro and Lee 2013), which was used by Marron and Steel (2000) and Andrés (2006b). They find that an increase on educational levels decreases software piracy. On the contrary Goel and Nelson (2009) find that literacy rate increase piracy. This apparently contradictory results may be explained by the no introduction of financial measures of education that can affect more directly the decision to pirate or not. We will introduce financial measures of education, namely expenditure on education.

Technological development can affect the access to software, but can also means more protection in the form of $R \& D$. Marron and Steel (2000) and Andrés (2006b) found that, more protection decreases software piracy. Nevertheless access to technology diffusion of Internet, computer based technologies and accessibility to information networks in a country enables both potential pirates and protectors of intellectual properties to do their jobs more effectively (Goel, Nelson 2009). Another study by Boyce (2011) find that people with Internet may or may not use illegal software, while the internet's speed determines the amount of information that can be retrieved at the same time as higher Internet speeds increase the ease to obtain both legal and illegal software. Use of pirated software also extends to IT professions that have more knowledge on how to pirate and put this software into its organizations, the main reason for this is related to economical and personal attitudes (Mishra et al. 2007). Education combined with Access to information can have an important effect on the use of pirated software.

Institutional factors can affect the correct functioning of governments. For example, when allocating funds to $R \& D$. Using "rule of law", Andrés (2006b) find that a good legal system decreases software piracy rates; also Goel and Nelson (2009) and Andrés and Goel (2011) find that more corrupt nations would have more piracy.

However, the studies that used a panel data have not considered that the dependent variable shows considerable persistence over time and we should use a dynamic framework. In this context as noticed for example by Baltagi (2008), the OLS estimator is biased and inconsistent even if the error terms are not serially correlated. Furthermore, the random effects estimator is also biased and even if the fixed effects estimator becomes consistent when $T$ gets large, Judson and Owen (1999) show that even for $T$ equal to 30 periods the bias can be as much as $20 \%$ of the true value of the coefficient of interest. Additionally, Soto (2009) reinforces these findings by showing that even when $N$ is not very large, the GMM estimators proposed by Arellano and Bover (1995) and Blundell and Bond (1998) display the best features in terms of small sample bias and precision. 


\section{Variables and possible effects}

Using cross-sectional data, Goel and Nelson (2009) introduced two main macroeconomic dimensions: the technological and the institutional dimension. Extending their results, we use a panel data analysis adding three additional macroeconomic dimensions: educational, labor and Access to information. A measure of income will be introduced, namely GDP (see for instance Andrés (2006a) and Goel and Nelson (2009)), which may affect software piracy losses.

We consider that piracy is a function of these dimensions: Technological, Educational, Access to Information, Institutional Dimension and Labor force as depicted in Figure 1.

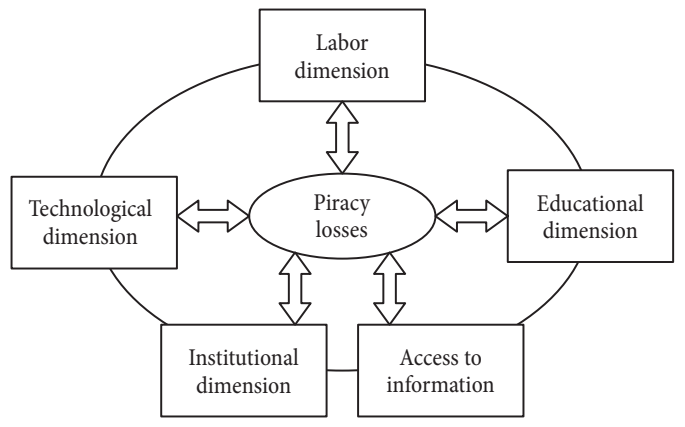

Fig. 1. Relationship between variables

Figure 1 also shows the relation between variables. Piracy is affecting all dimensions but also being influenced by them. Furthermore, all dimensions are linked together influencing each other. For example, education in a country will affect the type of jobs of workers, more service-oriented or more for the industry. In addition, the type of education will affect employment levels. More technologically advanced countries that rely on high $R \& D$, promote more effectively the protection of invents and the level of education of workers. Access to information can be seen as affecting all dimensions at the same time because more information in the form of knowledge will affect education levels and its quality, will permit access to innovations patented or not, and will also affect productivity of workers and access to employment opportunities advertised on the different Media. Institutional dimension also affect all dimensions at the same time; free countries have better education, technology, better access to information and qualified labor force.

The next subsections describe the main variables within each dimension.

\subsection{Technological dimension}

The first variable considered in this dimension is expenditure on research and development $(R \& D)$. It has been found to affect negatively software piracy (Marron, Steel 2000). As with Marron and Steel (2000) we introduce this variable that may also affect piracy losses. In our case this variable indicates investment that is made on software protection, namely software code. This variable also makes part of the educational dimension. 
Additional to this variable we introduce two additional measures that capture this dimension. To our knowledge no empirical work has studied these specific variables. They are the patent and the trademark applications done by residents and non-residents.

Patent applications are worldwide patent applications filed through the Patent Cooperation Treaty (PCT) procedure or with a national patent office for exclusive rights for an invention (this can be a product or a process). The protection of this product can reach up to 20 years. Patents can be filed by domestic or by foreign applicants.

Trademark applications filed are application to register a trademark with a national or regional Intellectual Property (IP) office. A trademark is a distinctive sign that identifies certain goods or services as those produced or provided by a specific region, person or enterprise. A trademark provides protection to the owner of the mark by ensuring the exclusive right to use it to identify goods or services, or to authorize another to use it in exchange for a license or royalty. The period of protection varies. Direct resident trademark applications are those filed by domestic applicants directly at a given national IP office while those that are filed by applicants from abroad are called "direct nonresident trademark applications". The registration of a patent or a trademark has costs for the firm, but these are necessary in order to protect their products.

All these variables are expected to have a negative effect on piracy losses although the existence of a patent is not sufficient to prevent piracy; the enforcement trough strict regulation is also necessary. More technological advanced countries have more legal protection and, at the same time, if the technology owners are closer to the market, they can detect more easily illegal software and start the legal procedures to fight it.

\subsection{Educational dimension}

In all countries there are a pre-determined number of years of schooling that a child needs to complete, and this number may vary from one country to another. During this period, children have specific subjects that require the usage of computers and Internet. This early introduction to new technologies will improve productivity of future workers. In some subjects, professors introduce the concept of illegal software and the risks associated with their use. The introduction of other concepts such as copyright can reduce the future use of illegal software. MacDonald and Fougere (2003) studied this effect analyzing Management Information Systems (MIS) textbooks. Previous research introduced the effective schooling years that students have (variables retrieved from the Barro and Lee (2013) dataset). Marron and Steel (2000) and Andrés (2006b) found that more schooling years reduce piracy. As this variable is not available annually, we will introduce a proxy variable that indicates years of schooling that a country offers. More years of schooling indicate that children understand and are aware about the consequence of using illegal software. This variable includes years of schooling on primary education based on the International Standard Classification of Education (henceforth, ISCED) 1997 (ISCED 1) and secondary education based on the ISCED 1997 (ISCED 2 and 3). This indicator reveals the total education that a country offers; it may or may not have a negative effect. 
Up to our knowledge, no previous research focused on the financial effects that expenditure on education can have on piracy. We will introduce a measure that reflects the expenditure that is made on education. More public expenditure on education as a percentage of GDP can reduce illegal software that students use; this will also result in more quality of education. This financial help can go both to public or private institutions. This variable is expected to affect negatively software piracy losses.

\subsection{Access to information}

Technology has evolved over the years. Today it is difficult or even impossible to live without it. Hardware and software industry have profited with these developments but, with the dissemination of the Internet, it was also possible to download huge amounts of information, some of which not legal, such as pirated software. Authors such as Goel and Nelson (2009) analyzed the effects that Internet and computer users have on piracy. Results showed that more users reduces piracy. More recently Boyce (2011) found that broadband penetration rate and Internet access reduce piracy. Most modern mobile phones uses an operating system, some of which may even replace the computer (in some specific tasks - the case of smartphones).

We will introduce four variables that measure the availability of information (telephone lines, fixed broadband Internet subscriber, Internet and mobile users).

Telephone lines are physical and fixed lines that connect a subscriber's terminal equipment to the public switched telephone network and that have a port on a telephone exchange. Integrated services digital network channels and fixed wireless subscribers are included. Fixed broadband Internet subscribers are the number of broadband subscribers with a digital subscriber line, cable modem, or other high-speed technology. Internet users are people with access to the worldwide network. Mobile cellular telephone subscriptions are subscriptions to a public mobile telephone service using cellular technology, which provide access to the public switched telephone network. Post-paid and prepaid subscriptions are included.

As all these variables increase the access to illegal software through the Internet, we think that these variables may have a positive effect on software piracy losses.

\subsection{Institutional dimension}

Past literature found that institutional factors play an important role on piracy (see Knack and Keefer 1995). Following Banerjee et al. (2005) and Goel and Nelson (2009), we introduce four institutional factors that can explain levels of software piracy; they are business freedom, trade freedom, freedom from corruption and financial freedom. Institutions also play an important aspect on the behavior of individuals towards the use of software or not (Akbulut 2014). As an example, low levels of corruption are associated with low or inefficient legal system which will encourage the usage of pirated software at school or at in 
the workplace (Akbulut 2014) ${ }^{2}$. Other external factors such as exposure to social norms and practices, being these good or bad will also affect their attitude towards illicit behavior (Cho et al. 2015). Another example of the perceived functioning of institutions is the moral belief that these work well, institutions can have an important effect on the use or not of pirated software (Siponen et al. 2012).

Business freedom indicates if firms can be established easily with little bureaucracy. This can affect piracy as in certain sectors, specific software must be used and certified; high levels of bureaucracy can lead firms to use unlicensed software, even with risks associated such as an external audit. Trade freedom indicates if countries promote trade or not, for example putting high tariff rates on foreign products such as software or hardware products. Putting high tariff rate on software purchase abroad can drastically increase software piracy, which will increase the probability of using illegal software. Freedom from corruption can tell us how the legal system work, if officials are corrupt and if illegal activities such as piracy pass unpunished. Finally, financial freedom measures banking efficiency and independence of government control. A correct functioning of the banking sector will promote credit to the economy, sometimes indispensable to purchase software in the case of expensive ones. Better institutions are associated with lower piracy losses.

\subsection{Labor force dimension}

Computer skills are acquired at school or at the workplace; these can range from browsing the Internet, sending e-mails, working on business applications such as word processors or spreadsheets, or even skills in software development. Different jobs require different types of software; some include imaging suits, others productivity or econometric tools, software development environments, etc. We will consider three variables that reflect the structure of the labor force of the population: employment in the primary sector (Agriculture), employment in the secondary sector (Industry) and employment in the tertiary sector (Services).

Employment in all sectors may have impact on software piracy losses. Firms want to maximize profit; in some cases, due to budgetary restrictions, employers can introduce some illicit software that will benefit both employers and employees. The introduction of illicit software has associated risks that are, for instance, the result from external audits that can impose severe fines. In spite of this, some firms may be willing to take them. Certain types of jobs, namely in the service sector, can be done from home, as in market research. In many cases workers wanting to do their jobs at home, due to reduced costs, may seek illicit software to implement their research. In these cases there is only a residual risk of external audits finding illicit software. This may lead an increase of software piracy losses.

\footnotetext{
${ }^{2}$ Although an important aspect on the behavior towards the usage of pirated software is difficult to measure and is not the main focus of this paper, the Theory of Planned Behavior (Ajzen 1991) and the Theory of Reasoned Action (Fishbein, Ajzen 1975) can provide an important starting point when doing empirical works using surveys. In psychology, the theory of planned behavior is a theory about the link between attitudes and behavior. The concept was proposed by Icek Ajzen to improve on the predictive power of the theory of reasoned action by including perceived behavioral control. For additional information see http://people.umass.edu/aizen/tpb.diag.html
} 
Additional to these variables, we introduce the education of the labor force. We will consider labor force with primary, secondary and tertiary education ${ }^{3}$. The labor force of a country plays an important role on the growth of the economy (Barro 2013). If it is constituted by labor force with low education, this will lead to low productivity and, consequently, to small economic growth. Also, if the labor force is constituted by highly qualified people, this will lead to increased productivity which improves the standards of living. These highly qualified employees will use computers and software. More education of the labor force characterizes a double-edged sword context: on one side there are more users of computers and software but, at the same time, some of the consumers will use illicit software.

Another measure that reflects both an income dimension and social dimension is the unemployment. We will use the total and the youth unemployment that reflects people within 15-24 years without work and the total unemployment rate. Both variables are expected to have a positive effect on piracy losses. An unemployed person has less disposable income and spends more time at home. Sometimes it is necessary to use certain software to start working (in the case of self-employment), but the lack of money can shift consumers from legal to illegal copies to fill their needs. Chen et al. (2010) found that unemployment has a negative effect (reduce) on software piracy rates. However their sample was small and reflected a small group of homogeneous countries where the psychological aspects could be determinant.

\section{Empirical evidence}

\subsection{Data, econometric specification and summary statistics}

Our dataset is constituted by macroeconomic variables retrieved from the World Development Indicators $(W D I)^{4}$ and the Heritage Foundation ${ }^{5}$ available for the countries present in the publications provided by the BSA and comprising 81 countries from 1995 until 2010. Variables were chosen based on their relevance and suitability and in their availability through all the period in the analysis. Due to the persistence of the piracy losses, we will use a dynamic panel data analysis, namely the Arellano and Bover (1995) and Blundell and Bond (1998) estimator. This estimator was developed because the lagged-level instruments of the original Arellano and Bond (1991) estimator become weak when the autoregressive process becomes too persistent or when the ratio of the variance of the panel-level effects and the variance of the idiosyncratic error becomes too large. The System GMM uses both level and first-difference of the lagged dependent variable as instruments. Furthermore Soto (2009) examined the properties of System GMM when the sample is small and the series is persistent, which is applicable to our dataset. This estimator was found to have lower bias and higher efficiency than the OLS or the fixed-effects estimator and the gain in efficiency from the two-step estimator is almost inexistent; both the one and two-step distributions are virtually the same. Based on the results we will report the One-Step System GMM.

The dependent variable is the piracy losses due to pirated software and it's measured in millions of dollars. The independent variables measure various dimensions of a country:

\footnotetext{
${ }^{3}$ We should note that the education of the labor force represents both a labor force dimension and educational dimension.

4 Technological, Educational, Access to Information and Labor force dimension were retrieved from the WDI indicators.

${ }^{5}$ Institutional dimension was retrieved from www.heritage.org.
} 
Technological dimensions, Educational dimension, Access to Information, Institutional Dimension and Labor Force dimension. In our analysis we will use the nominal GDP $(G D P)^{6}$ as a control variable.

The estimator used poses some problems, namely in the case of too many instruments. When the instruments count is high they may fail to expunge their endogenous components, biasing coefficient estimates toward those from non-instrumenting estimators, as discussed by (Roodman 2009a, 2009b). With the limitation of lags we overcome this problem, e.g., we will keep the number of instruments lower than the number of countries. The econometric specification is given in equation 1 as follows:

$$
\begin{aligned}
& \ln (\text { Losses })_{i t}=\beta_{i t}+\theta_{1} \ln (\text { Losses })_{i, t-1}+\alpha_{1} \ln (G D P)_{i t}+X_{i t} \alpha_{X}+Y_{i t} \alpha_{Y}+Z_{i t} \alpha_{Z}+ \\
& I_{i t} \alpha_{I}+W_{i t} \alpha_{W}+\alpha_{6} \text { Change }_{t}+v_{i}+\varepsilon_{i t},
\end{aligned}
$$

Where: $\quad X_{i t}^{\prime}=\left[R \& D_{i t} \ln (\text { Patres })_{i t} \ln (\text { Patnon })_{i t} \ln (\text { Tradres })_{i t} \ln (\text { Tradnon })_{i t}\right]$;

$Y_{i t}^{\prime}=\left[\right.$ Yschoolpri $_{i t}$ Yschoolsec $_{i t}$ Exppri $_{i t}$ Expsec $_{i t}$ Expter $_{i t}$ Pubexp $\left._{i t}\right]$;

$Z_{i t}^{\prime}=\left[\ln (\text { Fbis })_{i t} \ln (\text { Mobile })_{i t} \ln (\text { Phone })_{i t} \ln (\text { Net })_{i t}\right]$;

$I_{i t}^{\prime}=\left[\right.$ BusFreed $_{i t}$ TradFreed $_{i t}$ CorrFreed $_{i t}$ FinFreed $\left._{i t}\right]$;

$W_{i t}^{\prime}=\left[\right.$ Labp $_{i t}$ Labs $_{i t}$ Labt $_{i t}$ Empagri $_{i t}$ Empind $_{i t}$ Empserv $_{i t}$ Unemyouth $\left._{i t}\right]$,

$i=1, \ldots, 81$ represents the countries and $t=1995, \ldots, 2010$ the time periods.

The variable Losses is the piracy losses measured in millions of dollars and GDP is the Gross Domestic Product at current prices ${ }^{7}$.

$X_{i t}$ is a vector that represents the technological dimension and it's constituted by patents, trademarks and the research and development. $R \& D$ represents the research and development expenditure as a percentage of GDP, Patres are the patent applications done by residents, Patnon are the patent applications done by nonresidents. Tradres are the trademark applications done directly by residents and the Tradnon are the trademark applications done directly by nonresident. Both patents and trademarks are in logarithms.

$Y_{i t}$ is a vector of the education dimensions. It combines years of schooling and public expenditure in the different levels of education (primary, secondary and tertiary) as a percentage of GDP. Yschoolpri is the duration in years of primary education, Yschoolsec is the duration in years of secondary education. Pubexp represents public expenditure on education as a percentage of GDP.

The vector $Z_{i t}$ represents the various variables that represent access to information. Fbis is fixed broadband Internet subscribers, Mobile is mobile cellular subscriptions, Phone is the phone lines and Net is the access to the Internet. These variables are measured per 100 people. We introduce logarithms in this dimension.

Vector $I_{i t}$ represents the institutional dimension. Variables are business freedom (BusFreed), trade freedom (TradFreed), freedom from corruption (CorrFreed) and financial freedom (FinFreed).

\footnotetext{
${ }^{6}$ GDP is measured in current US dollars - this variable will be considered as endogenous and used to control the market dimension.

7 Additional to this we also considered $\ln$ (losses) $/ \ln (G D P)$ as dependent variable. Qualitatively the results are equal to the ones reported in this paper and they are available upon request to the authors.
} 
$W_{i t}$ is the vector of labor force. It reflects the labor force dimension and it's constituted by the labor force, type of employment and unemployment. Were Labp is the labor force with primary education, Labs is the labor force with secondary education, Labt is the labor force with tertiary education, Empagri is the employment in agriculture, Empind is the employment in industry, Empserv is the employment in the services sector. Unempyouth is the unemployment of people from 15 to 24 years old. We also introduce Unemp that is the total unemployment.

Additional to these variables, we use a dummy variable (Change) that reflects the change in methodology provided by the BSA. Before 2003 it will have a value of 0 and of 1 afterwards. We will also introduce a set of time dummies.

Table 1 presents the descriptive statistics of the various dimensions.

Table 1. Summary statistics

\begin{tabular}{|c|c|c|c|c|c|}
\hline Variables & Obs. & Mean & Std. Dev. & Min & $\operatorname{Max}$ \\
\hline Losses & 1217 & 353.80 & 929.37 & 0.902 & 9515 \\
\hline Losses/GDP & 1217 & 0.00082 & 0.00088 & 0.000088 & 0.016 \\
\hline$G D P$ & 1373 & 478804.7 & 1400089 & 1170.785 & $1.44 \mathrm{e}+07$ \\
\hline \multicolumn{6}{|c|}{ Labor Force dimension } \\
\hline Empagri & 1176 & 15.81 & 15.90 & 0.2 & 72.2 \\
\hline Empind & 1177 & 24.78 & 6.24 & 6.5 & 43.1 \\
\hline Empserv & 1177 & 58.79 & 14.42 & 13.3 & 87.4 \\
\hline$L a b p$ & 781 & 29.92 & 17.68 & 0 & 89 \\
\hline Labs & 775 & 43.13 & 16.89 & 2.9 & 80.2 \\
\hline Labt & 781 & 23.94 & 10.68 & 0 & 66.1 \\
\hline Unempyouth & 1006 & 17.43 & 9.33 & 2.2 & 629 \\
\hline Unemp & 1200 & 8.49 & 5.04 & 0.9 & 36.4 \\
\hline \multicolumn{6}{|c|}{ Technological dimension } \\
\hline Patres & 1186 & 12211.37 & 49331.09 & 2 & 384201 \\
\hline Patnon & 1196 & 6987.64 & 21961.23 & 1 & 248249 \\
\hline Tradres & 1174 & 23936.59 & 64011.48 & 1 & 973460 \\
\hline Tradnon & 1177 & 6356.59 & 7613.16 & 33 & 67838 \\
\hline$R \& D$ & 862 & 1.12 & 0.98 & 0.02 & 4.8 \\
\hline \multicolumn{6}{|c|}{ Educational dimension } \\
\hline Pubexp & 726 & 4.81 & 1.42 & $2.20 \mathrm{e}-06$ & 9.51 \\
\hline Yschoolpri & 1375 & 5.43 & 0.99 & 3 & 8 \\
\hline Yschoolsec & 1130 & 6.54 & 1.01 & 4 & 9 \\
\hline \multicolumn{6}{|c|}{ Access to Information dimension } \\
\hline $\mathrm{Net}$ & 1341 & 23.41 & 25.73 & 0.00 & 95.63 \\
\hline Fbis & 928 & 7.11 & 9.77 & 0.00 & 38.10 \\
\hline Phone & 1366 & 29.39 & 19.51 & 0.61 & 74.69 \\
\hline Mobile & 1367 & 48.56 & 45.15 & 0.00 & 195.57 \\
\hline \multicolumn{6}{|c|}{ Institutional dimension } \\
\hline BusFreed & 1256 & 50.59 & 24.53 & 10 & 100 \\
\hline TradFreed & 1256 & 70.62 & 13.37 & 36.3 & 100 \\
\hline CorrFreed & 1256 & 72.08 & 13.23 & 0 & 95 \\
\hline FinFreed & 1256 & 59.19 & 18.02 & 10 & 90 \\
\hline
\end{tabular}

Notes: Std. Dev. represents the standard deviation; Min the minimum and Max the maximum. 


\subsection{Empirical results}

This section presents the empirical results for the various dimensions, using the one step system GMM as it was explained before. Due to the nature of our dataset (extremely unbalanced when considering certain dimensions), we will split our analysis into 15 regressions.

For the System GMM to be applicable there must be no evidence of second order autocorrelation $\mathrm{AR}(2)$. Additional to this, instruments must be valid. To test this we report the Hansen test for validity of instruments (Hansen 1982). This test assumes, under the null hypothesis, that instruments are valid and it's a robust version of the Sargan test ${ }^{8}$. One problem that may occur is that it can be weakened by a proliferation of instruments and following Roodman (2009a) we also report the number of instruments. There is no evidence of $\operatorname{AR}(2)$ across all regressions. Furthermore, tests for the validity of instruments indicate that they are valid.

Table 2, 3 and 4 presents the regressions within each dimension. All of the regressions include control variables for the remaining dimensions. The control variable in the educational dimension is the result of the sum of primary and secondary schooling years: "School". In the Technological dimension, we used as control variables the sum of patents from residents and nonresidents, "In(Patents)" and the sum of trademark from residents and nonresidents, "In(Trademark)". When necessary, we also summed the total patents and trademarks, "In(Legal)"; this variable gives us a general idea of the overall demand for this kind of protection.

Table 2, columns 1 through 5 summarize the results from the labor force. From these results we conclude that the higher the share of people working in the services sector the lower will be the piracy losses. This can be seen in columns 1, 2 and 4 where the base sector (omitted variable) ${ }^{9}$ was the share of people working in the agriculture sector or in the industrial sector. In either case the share of people working in the services sector has a negative significant impact in the piracy losses. If we use the services sector as the base sector (column 3 or 5) the industrial and agricultural sectors have positive and significant impact (although the significance of the agricultural sector is not robust across specifications) pointing to the same conclusion: the higher the share in these sectors (and lower in the service sector) the higher will be the losses due to software piracy. This is an unexpected result.

As for the labor qualifications referred above, we have to omit one of the education variables and use it as the base case. In this case, the higher the share of workers with tertiary education the higher will be the losses due to piracy. Furthermore, the results indicate that is the division between the share of the workers with the tertiary education and the others that matters. This can be seen in columns 1 and 2 when we consider the share of labor with primary education; the estimated coefficient of the share with secondary education is close to zero and non-significant. The same result is obtained in column 4 when we use the

\footnotetext{
8 This test is also reported. It's not affected by the proliferation of instruments, but it's not robust.

${ }^{9}$ We should note that the sum of the three sectors adds up to 1 , so we cannot have the three variables simultaneously in the regression due to multicolinarity. In this case we consider one sector as the base one (and omit it from the regression) and the coefficients of the others sectors are the differential impacts between each sector and the base sector.
} 
secondary education share as the base and analyze the estimate of the share with primary education. This result is in line with what we expected.

Another important variable present in the labor force is the youth unemployment. This variable combined with the level of education of the labor force and access to technology will determine the use of software at home. This variable has always a positive impact, and it is significant in regressions 1 through 5 in which labor force and type of employment were present. As an additional robustness check we included total unemployment; significance was not present, nevertheless it maintains the positive coefficient.

Columns 6 through 10 show the different variables in the Technological dimension. In columns 9 and $10 \ln$ (Patents) has a significant positive impact on the losses, as $\ln$ (Trademarks) is non-significant. When a disaggregated analysis is made on the origin of patents and trademarks applicants (columns 6 to 8 ) the trademarks continue to not have a significant impact in losses. In terms of the number of patents, is the number of patents done by residents that have a significant impact on losses. A final variable that was found to have a strong effect in deterring software piracy losses was $R \& D$, which has always a negative coefficient. This can indicates that investment is being implemented correctly, namely in writing software code that protects software from hackers.

The positive coefficient of patents and the negative coefficient of $R \& D$ at first may appear odd, but it can be explained as follows: a company makes a breakthrough after many years of research, what will allow increased productivity, efficiency and protection for different components of the company products. This can also be extended to other products from other companies. In order to protect this discovery, the company will file a patent of the discovery that will allow some level of protection from other companies and from potential pirates. The existence of the patent by itself it's not synonym of protection; national Intellectual Property offices must also be able to enforce and protect them. The positive coefficient can be explained by the existence of patents that are the result of research, but the lack of power exerted by national IP offices will not prevent piracy in spite of the existence of patents.

All regressions control for institutional dimensions. Tests were performed using variables that represent institutional factors; the reported ones provide the best estimates. Only Freedom from Corruption Index (CorrFreed) (column 8) presented significance. Results show that low levels of corruption leads to less piracy losses. This confirms the results of Goel and Nelson (2009) and Andrés and Goel (2011). This index ranges from 0, high corruption, to 100 , no corruption.

Regarding education we included financial and non-financial measures. The first perspective was never considered in previous studies and, in the second case, variables used on previous research were literacy rate and the average years of schooling of people age 25 and over (Barro, Lee 2013). Both of these variables have the problem of data availability. To overcome this problem we will introduce a proxy variable that indicates the years of schooling of both primary and secondary education offered by the educational system of a country. This variable is not perfect as it omits the education attained, but it offers us a benchmark, furthermore, in some countries increasing this variable may not be feasible. 
Table 2. Dynamic model using one-step System GMM

\begin{tabular}{|c|c|c|c|c|c|}
\hline Variables & 1 & 2 & 3 & 4 & 5 \\
\hline L.ln(losses) & $\begin{array}{c}0.572^{\star \star *} \\
(6.930) \\
\end{array}$ & $\begin{array}{c}0.513^{\star * \star} \\
(5.121) \\
\end{array}$ & $\begin{array}{c}0.586^{\star * *} \\
(6.310) \\
\end{array}$ & $\begin{array}{c}0.579^{* * *} \\
(7.081) \\
\end{array}$ & $\begin{array}{c}0.460^{\star * \star} \\
(4.072) \\
\end{array}$ \\
\hline $\ln (G D P)$ & $\begin{array}{l}0.282^{\star \star} \\
(2.524)\end{array}$ & $\begin{array}{c}0.308^{\star * *} \\
(3.009)\end{array}$ & $\begin{array}{c}0.326^{* * *} \\
(3.397)\end{array}$ & $\begin{array}{l}0.274^{\star *} \\
(2.563)\end{array}$ & $\begin{array}{c}0.404^{\star \star} \\
(2.312)\end{array}$ \\
\hline $\ln ($ Mobile) & $\begin{array}{c}-0.005 \\
(-0.124)\end{array}$ & $\begin{array}{c}-0.025 \\
(-0.627)\end{array}$ & & & \\
\hline $\ln (\text { Mobile })^{*}$ Change & & $\begin{array}{l}0.348^{\star *} \\
(2.168)\end{array}$ & & & \\
\hline $\ln$ (Phone) & & & $\begin{array}{c}0.148 \\
(0.701) \\
\end{array}$ & $\begin{array}{c}0.054 \\
(0.347) \\
\end{array}$ & \\
\hline ln(Phone) ${ }^{\star}$ Change & & & $\begin{array}{c}0.018 \\
(0.098)\end{array}$ & $\begin{array}{c}-0.102 \\
(-0.600)\end{array}$ & \\
\hline $\ln$ (Fbis) & & & & & $\begin{array}{c}0.026 \\
(0.731) \\
\end{array}$ \\
\hline $\ln (\text { Fbis })^{*}$ Change & & & & & $\begin{array}{c}0.066 \\
(1.014) \\
\end{array}$ \\
\hline Empagric & & & $\begin{array}{l}0.016^{*} \\
(1.720) \\
\end{array}$ & $\begin{array}{c}-0.021 \\
(-1.473) \\
\end{array}$ & $\begin{array}{l}0.019^{\star *} \\
(2.368)\end{array}$ \\
\hline Empind & $\begin{array}{l}0.021^{\star} \\
(1.727)\end{array}$ & $\begin{array}{c}0.016 \\
(1.410)\end{array}$ & $\begin{array}{l}0.026^{\star *} \\
(2.344)\end{array}$ & & $\begin{array}{l}0.028^{\star *} \\
(2.523)\end{array}$ \\
\hline Empserv & $\begin{array}{l}-0.012^{\star *} \\
(-2.159)\end{array}$ & $\begin{array}{l}-0.013^{\star *} \\
(-1.972)\end{array}$ & & $\begin{array}{c}-0.033^{\star * *} \\
(-3.029)\end{array}$ & \\
\hline Labp & & & $\begin{array}{l}-0.014^{\star} \\
(-1.734)\end{array}$ & $\begin{array}{c}0.004 \\
(0.685)\end{array}$ & $\begin{array}{l}-0.015^{\star} \\
(-1.729)\end{array}$ \\
\hline Labs & $\begin{array}{c}-0.004 \\
(-0.756)\end{array}$ & $\begin{array}{c}-0.004 \\
(-0.604)\end{array}$ & $\begin{array}{l}-0.014^{*} \\
(-1.753)\end{array}$ & & $\begin{array}{l}-0.013^{*} \\
(-1.839)\end{array}$ \\
\hline Labt & $\begin{array}{l}0.016^{\star *} \\
(2.009)\end{array}$ & $\begin{array}{c}0.009 \\
(0.821) \\
\end{array}$ & & $\begin{array}{l}0.021^{* *} \\
(2.328)\end{array}$ & \\
\hline Unempyouth & $\begin{array}{l}0.013^{\star *} \\
(2.279) \\
\end{array}$ & $\begin{array}{l}0.014^{\star *} \\
(2.522)\end{array}$ & $\begin{array}{l}0.012^{\star *} \\
(2.158) \\
\end{array}$ & $\begin{array}{l}0.013^{\star \star} \\
(2.241) \\
\end{array}$ & $\begin{array}{l}0.010^{* *} \\
(2.182) \\
\end{array}$ \\
\hline $\ln$ (Patents) & $\begin{array}{c}-0.006 \\
(-0.199) \\
\end{array}$ & $\begin{array}{c}0.001 \\
(0.022) \\
\end{array}$ & $\begin{array}{c}-0.022 \\
(-0.535) \\
\end{array}$ & $\begin{array}{c}-0.007 \\
(-0.200) \\
\end{array}$ & $\begin{array}{c}-0.001 \\
(-0.049) \\
\end{array}$ \\
\hline $\ln ($ Trademarks $)$ & $\begin{array}{c}0.071 \\
(1.481)\end{array}$ & $\begin{array}{l}0.090^{\star *} \\
(2.042)\end{array}$ & $\begin{array}{c}0.048 \\
(0.718)\end{array}$ & $\begin{array}{c}0.069 \\
(1.195)\end{array}$ & $\begin{array}{c}0.054 \\
(0.797)\end{array}$ \\
\hline School & $\begin{array}{c}0.021 \\
(0.220)\end{array}$ & $\begin{array}{c}0.048 \\
(0.464)\end{array}$ & $\begin{array}{c}-0.153 \\
(-1.161) \\
\end{array}$ & $\begin{array}{c}-0.011 \\
(-0.119) \\
\end{array}$ & $\begin{array}{c}-0.034 \\
(-0.248) \\
\end{array}$ \\
\hline TradFreed & $\begin{array}{c}0.009 \\
(1.410)\end{array}$ & & & $\begin{array}{c}0.009 \\
(1.222)\end{array}$ & $\begin{array}{c}0.001 \\
(0.070)\end{array}$ \\
\hline BusFreed & & $\begin{array}{c}0.002 \\
(0.643)\end{array}$ & $\begin{array}{c}0.008 \\
(1.587)\end{array}$ & & \\
\hline Change & $\begin{array}{c}0.413^{\star * *} \\
(4.124)\end{array}$ & $\begin{array}{l}-1.000^{*} \\
(-1.657)\end{array}$ & $\begin{array}{c}0.351 \\
(0.497)\end{array}$ & $\begin{array}{c}0.749 \\
(1.161)\end{array}$ & $\begin{array}{l}0.359^{* *} \\
(2.349)\end{array}$ \\
\hline Observations & 501 & 501 & 501 & 507 & 415 \\
\hline Countries/Instruments & $61 / 53$ & $61 / 53$ & $61 / 53$ & $61 / 53$ & $59 / 51$ \\
\hline AR1 & $-4.596^{* * *}$ & $-4.334^{* * *}$ & $-4.489^{* * *}$ & $-4.591^{* * *}$ & $-3.587^{\star * *}$ \\
\hline AR2 & -0.0340 & 0.417 & -0.441 & -0.339 & 0.300 \\
\hline Sargan & $80.39^{\star * *}$ & $78.18^{\star * *}$ & $78.64^{\star * *}$ & $73.51^{\star \star \star}$ & $79.39^{* * *}$ \\
\hline Hansen & 42.47 & 37.52 & 40.84 & 37.26 & 42.20 \\
\hline
\end{tabular}

Notes: Dependent variable is $\ln$ (losses). Robust t-statistics in parentheses; ${ }^{\star},{ }^{* \star}$ and ${ }^{* \star *}$ represent statistical significance at $10 \%, 5 \%$ and $1 \%$ respectively. $L \cdot \ln$ (losses) and $L \cdot \ln (G D P)$ were considered as two endogenous instruments. Only one lag was used as instrument. 
Table 3. Dynamic model using one-step System GMM (cont.)

\begin{tabular}{|c|c|c|c|c|c|}
\hline Variables & 6 & 7 & 8 & 9 & 10 \\
\hline L. $\ln$ (losses) & $\begin{array}{c}0.514^{* * *} \\
(5.457)\end{array}$ & $\begin{array}{c}0.610^{* * *} \\
(6.410)\end{array}$ & $\begin{array}{c}0.552^{\star * *} \\
(5.570)\end{array}$ & $\begin{array}{c}0.544^{* * *} \\
(5.028)\end{array}$ & $\begin{array}{c}0.541^{* * *} \\
(4.909)\end{array}$ \\
\hline $\ln (G D P)$ & $\begin{array}{c}0.347^{* * *} \\
(3.033)\end{array}$ & $\begin{array}{l}0.294^{\star *} \\
(2.143)\end{array}$ & $\begin{array}{c}0.448^{\star * *} \\
(2.706)\end{array}$ & $\begin{array}{c}0.387^{* * *} \\
(2.843)\end{array}$ & $\begin{array}{c}0.387^{* * *} \\
(2.788)\end{array}$ \\
\hline $\ln ($ Mobile) & $\begin{array}{c}-0.013 \\
(-0.145)\end{array}$ & $\begin{array}{c}0.075 \\
(0.679)\end{array}$ & $\begin{array}{c}0.076 \\
(0.674)\end{array}$ & $\begin{array}{l}0.169^{\star *} \\
(2.166)\end{array}$ & $\begin{array}{c}0.148 \\
(1.642)\end{array}$ \\
\hline $\ln (\text { Mobile })^{*}$ Change & $\begin{array}{c}0.267^{\star} \\
(1.802)\end{array}$ & $\begin{array}{c}0.009 \\
(0.054)\end{array}$ & $\begin{array}{c}-0.025 \\
(-0.156)\end{array}$ & & $\begin{array}{c}0.097 \\
(0.621)\end{array}$ \\
\hline $\ln (\mathrm{Fbis})$ & $\begin{array}{c}0.002 \\
(0.044)\end{array}$ & $\begin{array}{c}-0.016 \\
(-0.617)\end{array}$ & $\begin{array}{c}-0.004 \\
(-0.177)\end{array}$ & $\begin{array}{c}0.003 \\
(0.101) \\
\end{array}$ & $\begin{array}{c}0.005 \\
(0.174)\end{array}$ \\
\hline Unemp & $\begin{array}{c}0.000 \\
(0.011)\end{array}$ & $\begin{array}{c}-0.019 \\
(-1.245)\end{array}$ & $\begin{array}{c}-0.013 \\
(-0.854)\end{array}$ & & \\
\hline Unempyouth & & & & $\begin{array}{c}0.011 \\
(1.268)\end{array}$ & $\begin{array}{c}0.011 \\
(1.316)\end{array}$ \\
\hline School & $\begin{array}{c}0.079 \\
(0.985)\end{array}$ & $\begin{array}{c}-0.062 \\
(-0.614)\end{array}$ & $\begin{array}{c}0.032 \\
(0.334)\end{array}$ & $\begin{array}{c}0.058 \\
(0.553)\end{array}$ & $\begin{array}{c}0.067 \\
(0.636)\end{array}$ \\
\hline$R \& D$ & $\begin{array}{c}-0.307^{* * *} \\
(-3.188)\end{array}$ & $\begin{array}{l}-0.134^{*} \\
(-1.901)\end{array}$ & $\begin{array}{c}-0.021 \\
(-0.290)\end{array}$ & $\begin{array}{l}-0.260^{* *} \\
(-2.396)\end{array}$ & $\begin{array}{l}-0.265^{\star *} \\
(-2.500)\end{array}$ \\
\hline $\ln$ (Patres) & $\begin{array}{l}.131^{\star *} \\
(2.571)\end{array}$ & & & & \\
\hline $\ln ($ Patnon $)$ & $\begin{array}{c}0.017 \\
(0.491)\end{array}$ & & & & \\
\hline $\ln$ (Tradres) & & $\begin{array}{c}0.123 \\
(1.505)\end{array}$ & $\begin{array}{c}-0.052 \\
(-0.433)\end{array}$ & & \\
\hline $\ln ($ Tradnon $)$ & & $\begin{array}{c}-0.082 \\
(-1.429)\end{array}$ & $\begin{array}{c}0.006 \\
(0.098)\end{array}$ & & \\
\hline $\ln ($ Patents $)$ & & & & $\begin{array}{l}0.056^{* *} \\
(2.009)\end{array}$ & $\begin{array}{l}0.058^{\star *} \\
(2.163)\end{array}$ \\
\hline $\ln$ (Trademarks) & & & & $\begin{array}{c}-0.036 \\
(-0.665)\end{array}$ & $\begin{array}{c}-0.037 \\
(-0.668)\end{array}$ \\
\hline CorrFreed & & & $\begin{array}{l}-0.008^{\star *} \\
(-2.000)\end{array}$ & & \\
\hline TradFreed & $\begin{array}{c}-0.004 \\
(-0.586) \\
\end{array}$ & & & $\begin{array}{c}0.001 \\
(0.127)\end{array}$ & $\begin{array}{c}-0.001 \\
(-0.141) \\
\end{array}$ \\
\hline Change & $\begin{array}{c}-0.664 \\
(-1.134)\end{array}$ & $\begin{array}{c}0.311 \\
(0.498)\end{array}$ & $\begin{array}{c}0.459 \\
(0.719)\end{array}$ & $\begin{array}{c}0.345^{* * *} \\
(2.855)\end{array}$ & $\begin{array}{c}-0.062 \\
(-0.099)\end{array}$ \\
\hline Observations & 478 & 473 & 472 & 411 & 411 \\
\hline Countries/Instruments & $75 / 51$ & $75 / 51$ & $75 / 51$ & $66 / 51$ & $66 / 51$ \\
\hline AR1 & $-3.035^{* * *}$ & $-3.277^{\star * *}$ & $-3.345^{* * *}$ & $-3.6065^{\star * *}$ & $-3.5835^{\star * \star}$ \\
\hline AR2 & 0.499 & 0.195 & 0.309 & -0.200 & -0.142 \\
\hline Sargan & $62.125^{\star * *}$ & $70.545^{\star \star \star}$ & $67.595^{* * *}$ & $58.875^{\star * \star}$ & $58.805^{\star \star \star}$ \\
\hline Hansen & 35.78 & 44.43 & 42.84 & 33.86 & 33.36 \\
\hline p-value & {$[0.385]$} & {$[0.132]$} & {$[0.142]$} & {$[0.523]$} & [0.499] \\
\hline
\end{tabular}


Table 4. Dynamic model using one-step System GMM (cont.)

\begin{tabular}{|c|c|c|c|c|c|}
\hline Variables & 11 & 12 & 13 & 14 & 15 \\
\hline L. $\ln ($ losses $)$ & $\begin{array}{c}0.555^{\star * *} \\
(6.908)\end{array}$ & $\begin{array}{c}0.551^{\star * *} \\
(7.951)\end{array}$ & $\begin{array}{c}0.541^{* * *} \\
(7.338)\end{array}$ & $\begin{array}{c}0.577^{* * *} \\
(6.213)\end{array}$ & $\begin{array}{c}0.617^{* * *} \\
(6.180)\end{array}$ \\
\hline $\ln (G D P)$ & $\begin{array}{c}0.450^{\star * *} \\
(5.051)\end{array}$ & $\begin{array}{c}0.360^{\star * \star} \\
(4.260)\end{array}$ & $\begin{array}{c}0.382^{\star * *} \\
(4.743)\end{array}$ & $\begin{array}{c}0.387^{* * *} \\
(3.816)\end{array}$ & $\begin{array}{c}0.297^{* * *} \\
(2.914)\end{array}$ \\
\hline $\ln ($ Mobile) & $\begin{array}{c}-0.019 \\
(-0.548)\end{array}$ & $\begin{array}{c}-0.022 \\
(-0.689)\end{array}$ & $\begin{array}{c}-0.012 \\
(-0.349)\end{array}$ & & $\begin{array}{c}0.029 \\
(0.427) \\
\end{array}$ \\
\hline $\ln (\text { Mobile })^{*}$ Change & & & & & $\begin{array}{c}0.356^{\star * *} \\
(2.690)\end{array}$ \\
\hline $\ln (\mathrm{Net})$ & & & & $\begin{array}{l}-0.100^{*} \\
(-1.886) \\
\end{array}$ & $\begin{array}{l}-0.158^{\star} \\
(-1.806) \\
\end{array}$ \\
\hline$R \& D$ & & & & $\begin{array}{l}-0.143^{\star} \\
(-1.785) \\
\end{array}$ & $\begin{array}{c}-0.181^{\star *} \\
(-2.123) \\
\end{array}$ \\
\hline Yschoolpri & $\begin{array}{l}-0.242^{\star} \\
(-1.830)\end{array}$ & $\begin{array}{c}-0.236^{\star * *} \\
(-3.343)\end{array}$ & $\begin{array}{c}-0.259^{* * *} \\
(-3.522)\end{array}$ & & \\
\hline Yschoolsec & $\begin{array}{c}-0.037 \\
(-0.272)\end{array}$ & $\begin{array}{c}-0.112 \\
(-1.267)\end{array}$ & $\begin{array}{c}-0.026 \\
(-0.245)\end{array}$ & & \\
\hline Pubexp & & & & $\begin{array}{l}0.150^{* *} \\
(2.382)\end{array}$ & $\begin{array}{c}0.180^{* * *} \\
(2.771)\end{array}$ \\
\hline$L a b p$ & $\begin{array}{l}-0.016^{\star *} \\
(-2.473)\end{array}$ & $\begin{array}{c}0.002 \\
(0.438)\end{array}$ & & & \\
\hline Labs & $\begin{array}{c}-0.021^{\star * *} \\
(-2.576)\end{array}$ & & $\begin{array}{l}-0.010^{*} \\
(-1.847) \\
\end{array}$ & & \\
\hline Labt & & $\begin{array}{l}0.011^{\star} \\
(1.890)\end{array}$ & $\begin{array}{c}0.014^{* * *} \\
(2.580)\end{array}$ & & \\
\hline Unemp & $\begin{array}{c}0.001 \\
(0.054) \\
\end{array}$ & $\begin{array}{c}-0.010 \\
(-1.014) \\
\end{array}$ & $\begin{array}{c}-0.005 \\
(-0.484) \\
\end{array}$ & $\begin{array}{c}-0.010 \\
(-0.682) \\
\end{array}$ & $\begin{array}{c}0.003 \\
(0.153) \\
\end{array}$ \\
\hline $\ln ($ Legal $)$ & $\begin{array}{c}-0.035^{\star} \\
(-1.788) \\
\end{array}$ & $\begin{array}{c}-0.005 \\
(-0.207)\end{array}$ & $\begin{array}{c}-0.010 \\
(-0.363)\end{array}$ & $\begin{array}{c}0.010 \\
(0.543)\end{array}$ & $\begin{array}{c}0.042 \\
(1.657) \\
\end{array}$ \\
\hline CorrFreed & $\begin{array}{c}-0.002 \\
(-0.655)\end{array}$ & & & $\begin{array}{c}-0.004 \\
(-0.922)\end{array}$ & \\
\hline TradFreed & & $\begin{array}{c}0.001 \\
(0.190)\end{array}$ & $\begin{array}{c}0.002 \\
(0.381) \\
\end{array}$ & & \\
\hline FinFreed & & & & & $\begin{array}{c}-0.002 \\
(-0.468) \\
\end{array}$ \\
\hline \multirow[t]{2}{*}{ Change } & $0.379^{* * *}$ & $0.426^{* * *}$ & $0.411^{\star \star \star}$ & $0.478^{\star * *}$ & $-1.008^{*}$ \\
\hline & $(4.357)$ & $(5.414)$ & $(4.636)$ & $(4.650)$ & $(-1.917)$ \\
\hline Observations & 515 & 521 & 515 & 441 & 441 \\
\hline Countries/Instruments & $64 / 55$ & $64 / 55$ & $64 / 55$ & $66 / 47$ & $66 / 47$ \\
\hline AR1 & $-4.290^{\star \star \star}$ & $-4.281^{\star * *}$ & $-4.145^{\star \star \star}$ & $-3.740^{\star * *}$ & $-3.824^{* * *}$ \\
\hline AR2 & -0.387 & -0.469 & -0.275 & -0.552 & 0.126 \\
\hline Sargan & $73.64^{* * *}$ & $93.63^{\star * *}$ & $80.82^{\star * *}$ & $73.21^{\star * *}$ & $51.85^{\star * *}$ \\
\hline Hansen & 41.64 & 46.05 & 44.08 & 43.78 & 35.21 \\
\hline $\mathrm{p}$-value & {$[0.357]$} & {$[0.203]$} & {$[0.265]$} & [0.099] & {$[0.276]$} \\
\hline
\end{tabular}


Additional to this, we will introduce a variable that indicates spending on education, which reflects how Governments can improve education will be introduced. Columns 11 through 15 show the results.

Columns 11 through 13 present the years of schooling. As in the labor force dimension, we include the education of the labor force; results are robust. An increase of years of primary and secondary education appears to have a negative impact on piracy losses, but only in the first case this variable is significant across all regressions with a coefficient of around -0.250 .

The financial aspects of education are presented in columns 14 and 15. Public spending on education can go both to public or private institutions and depending on the different levels of education different resources are allocated. Public expenditure on education has a positive effect and is significant at $1 \%$ (column 15). This public spending can also go directly to students through direct help in the form of scholarships. There are many ways a student can use this help. Some examples are: acquisition of computer, software, access to the Internet, etc. This will increase the availability to digital content such as music, software and movies. We were expecting a negative impact; nevertheless this may indicate that more access to digital content can also increase the availability of illegal software. Only with increase awareness this problem can be mitigated.

Several alternative hypotheses were considered with different variables within the dimension that reflect the access to information. The access to Internet - $\ln (\mathrm{Net})$ - has a negative and significant effect on losses (columns 14 and 15), while the access to a broadband connection has no impact on losses (columns 5 through 10). This is clearly unexpected, but seems that access to Internet reduces the losses because of increased awareness of the problem by the consumers, because countries with a higher share of people connected to the Internet are able to track those who use illicit software, or simply because you can download and buy the software directly from the original company and not from local intermediaries - many of them may be selling pirated software. These results are in accordance with the findings of Boyce (2011).

\section{Conclusions}

This paper examined the impact of several dimensions that might explain the phenomenon of software piracy losses. Due to the nature of our dataset and the availability of information we opted to use a dynamic panel data analysis that could track the growth of piracy losses over time. We found that several dimensions could explain this growth; Technological, Educational, Institutional, Access to Information and Labor Force.

In the technological dimensions, patents and trademarks were analyzed as one of the explanations of software piracy. Patents were significant and positive; they grant a protection for those who innovate but other factors must be considered (that could explain the positive sign) such as the effectiveness of this protection and the punishment for those who infringe the law. Our findings suggest that more protection in the form of trademarks or patents can in some cases reduce losses. Another variable introduced was $R \& D$, which was found to have a negative effect on software piracy losses. 
The results from the education dimensions show that more years of schooling have a deterrent effect on piracy, namely in primary education. This indicates that promoting measures in early ages of the educational system can reduce future illicit behavior. When our analysis turns to financial aspects of education, more spending means more piracy losses; this expenditure can go to better curriculum.

The correct functioning of institutions can reduce piracy. Our results show that less corruption is associated with lower piracy losses. As national authorities set the example for citizens, if governments apply the law effectively and abide by it, this will transmit authority to citizens.

More Access to information has mixed results on piracy losses. This can be explained by the nature of the different devices used to access digital content, for example through the Internet.

The labor force was one of the dimensions considered. Higher levels of education resulted in more losses, but a higher share of employment in the service sector has a negative impact on losses. This might be a result of more access to information by employees with higher education and the capability to track illicit content through internal audits in the service sector.

In 2012, the ninth edition of the BSA (2012) global piracy study presented some "blueprints" to reduce, or at least mitigate piracy. One of these solutions is the increase of "public education" and awareness. Results show that more education reduces piracy although special attention must be made on educational expenditure. Additional to this, BSA also recommends a better enforcement of the "WIPO copyright treaty", "better enforcement mechanisms", namely strong copyright laws, "dedicated resources", through for example specialized IP enforcement units and "lead by example". For these mechanisms to be applied efficiently, better attention should be given to laws as we found that more patents can lead to more piracy. Additionally, nations free of corruption can lead by example, namely by using legal software but also promoting cross-border cooperation among police and other enforcement agencies that deal with intellectual property rights related crimes.

We should note that these policy recommendations don't pay attention to the sectors of activity as well as the structure of the labor force. Better attention must be done on the different sectors of activity that are the building blocks of the economy of a country, namely employment in the industrial sector as it was found to increase piracy losses. More employees with tertiary education increase piracy losses. Proposing better audit mechanisms to governments should be addressed by the BSA as well as continuous learning in the workplace for both employees and employers.

Although this paper provides new insights on the major macroeconomic determinants of losses caused by piracy, lack of data on some dimensions reduced the number of observations and weakened the possible conclusions. Further analysis using panel data and introducing large time span should be followed. Using small group of countries such as the European Union, or an in deep analysis of the various dimensions, could provide valuable tools for policymakers as changes in education can only be viewed in the long-run. As an example, a detailed analysis on the effects of the structure of the labor force and its education with a disaggregation based both on levels of development and continents could provide new insight. 


\section{References}

Ajzen, I. 1991. The theory of planned behavior, Organizational Behavior and Human Decision Processes 50(2): 179-211. http://dx.doi.org/10.1016/0749-5978(91)90020-T

Akbulut, I. 2014. Exploration of the antecedents of digital piracy through a structural equation model, Computers \& Education 78: 294-305. http://dx.doi.org/10.1016/j.compedu.2014.06.016.

Andrés, A. R. 2006a. The relationship between copyright software protection and piracy: evidence from Europe, European Journal of Law and Economics 21(1): 29-51. http://dx.doi.org/10.1007/s10657-006-5670-5

Andrés, A. R. 2006b. Software piracy and income inequality, Applied Economics Letters 13(2): 101-105. http://dx.doi.org/10.1080/13504850500390374

Andrés, A. R.; Asongu, S. 2013. Fighting software piracy: which governance tools matter in Africa?, Journal of Business Ethics 118(3): 667-682. http://dx.doi.org/10.1007/s10551-013-1620-7

Andrés, A. R.; Goel, R. K. 2011. Corruption and software piracy: a comparative perspective, Policy \& Internet 3(3): 1-22. http://dx.doi.org/10.2202/1944-2866.1088

Andrés, A. R.; Goel, R. K. 2012. Does software piracy affect economic growth? Evidence across countries, Journal of Policy Modeling 34(2): 284-295. http://dx.doi.org/10.1016/j.jpolmod.2011.08.014

Arellano, M.; Bond, S. 1991. Some tests of specification for panel data: Monte Carlo evidence and an application to employment equations, The Review of Economic Studies 58(2): 277-297. http://dx.doi.org/10.2307/2297968

Arellano, M.; Bover, O. 1995. Another look at the instrumental variable estimation of error-components models, Journal of Econometrics 68(1): 29-51. http://dx.doi.org/10.1016/0304-4076(94)01642-D

Asongu, S. 2012. Fighting software piracy in Africa: how do legal origins and IPRs protection channels matter?, Journal of the Knowledge Economy, 1-22. http://dx.doi.org/10.1007/s13132-012-0137-0

Baltagi, B. 2008. Econometric analysis of panel data. 4th ed. John Wiley \& Sons.

Banerjee, D.; Khalid, A. M.; Sturm, J. E. 2005. Socio-economic development and software piracy. An empirical assessment, Applied Economics 37(18): 2091-2097. http://dx.doi.org/10.1080/00036840500293276

Barro, R. J. 2013. Education and economic growth, Annals of Economics and Finance 14(2): 301-328.

Barro, R. J.; Lee, J. W. 2013. A new data set of educational attainment in the world, 1950-2010, Journal of Development Economics 104(0): 184-198. http://dx.doi.org/10.1016/j.jdeveco.2012.10.001

Blundell, R.; Bond, S. 1998. Initial conditions and moment restrictions in dynamic panel data models, Journal of Econometrics 87(1): 115-143. http://dx.doi.org/10.1016/S0304-4076(98)00009-8

Boyce, J. A. 2011. International determinants of software piracy: Master's thesis [online]. California State University [cited 30 January 2013]. Available from Internet: http://hdl.handle.net/10211.9/1087

BSA. 2012. Shadow market: 2011 BSA Global Software Piracy Study. Business Software Alliance.

Chen, C. C.; Chen, C. P.; Yeh, C. Y. 2010. Determinants of software piracy: evidence from far East countries, Journal of International and Global Economic Studies 3(2).

Cho, H.; Chung, S.; Filippova, A. 2015. Perceptions of social norms surrounding digital piracy: the effect of social projection and communication exposure on injunctive and descriptive social norms, Computers in Human Behavior 48: 506-515. http://dx.doi.org/10.1016/j.chb.2015.02.018

Fishbein, M.; Ajzen, I. 1975. Belief, attitude, intention and behavior: an introduction to theory and research. Boston: Addison Wesley.

Goel, R. K.; Nelson, M. 2009. Determinants of software piracy: economics, institutions, and technology, The Journal of Technology Transfer 34(6): 637-658. http://dx.doi.org/10.1007/s10961-009-9119-1

Goel, R. K.; Nelson, M. A. 2012. Shadow economy and international software piracy, Applied Financial Economics 22(23): 1951-1959. http://dx.doi.org/10.1080/09603107.2012.690848 
Hansen, L. P. 1982. Large sample properties of generalized method of moments estimators, Econometrica 50(4): 1029-1054. http://dx.doi.org/10.2307/1912775

Judson, R. A.; Owen, A. L. 1999. Estimating dynamic panel data models: a guide for macroeconomists, Economics Letters 65(1): 9-15. http://dx.doi.org/10.1016/S0165-1765(99)00130-5

Knack, S.; Keefer, P. 1995. Institutions and economic performance: cross-country tests using alternative institutional measures, Economics \& Politics 7(3): 207-227. http://dx.doi.org/10.1111/j.1468-0343.1995.tb00111.x

MacDonald, L. E.; Fougere, K. T. 2003. Software piracy: a study of the extent of coverage in introductory MIS textbooks, Journal of Information Systems Education 13(4).

Marron, D. B.; Steel, D. G. 2000. Which countries protect intellectual property? The case of software piracy, Economic Inquiry 38(2): 159-174. http://dx.doi.org/10.1111/j.1465-7295.2000.tb00011.x

Mishra, A.; Akman, I.; Yazici, A. 2007. Organizational software piracy: an empirical assessment, Behaviour \& Information Technology 26(5): 437-444. http://dx.doi.org/10.1080/01449290500483577

Poddar, S. 2005. Why software piracy rates differ - a theoretical analysis. National University of Singapore, Department of Economics.

Roodman, D. 2009a. How to do xtabond2: an introduction to difference and system GMM in Stata, Stata Journal 9(1): 86-136.

Roodman, D. 2009b. A note on the theme of too many instruments, Oxford Bulletin of Economics and Statistics 71(1): 135-158. http://dx.doi.org/10.1111/j.1468-0084.2008.00542.x

Siponen M.; Vance, A.; Willison, R. 2012. New insights into the problem of software piracy: the effects of neutralization, shame, and moral beliefs, Information \& Management 49(7-8): 334-341. http://dx.doi.org/10.1016/j.im.2012.06.004

Soto, M. 2009. System GMM estimation with a small sample: Barcelona Graduate School of Economics.

van Kranenburg, H.; Hogenbirk, A. 2005. Multimedia, entertainment, and business software copyright piracy: a cross-national study, Journal of Media Economics 18(2): 109-129.

http://dx.doi.org/10.1207/s15327736me1802_3

Nicolas Dias GOMES received its $\mathrm{PhD}$ in Economics at Faculty of Economics of Coimbra University. The main areas of research are the economics of Intellectual Property Rights, macroeconomics.

Pedro André CERQUEIRA received its $\mathrm{PhD}$ in Economics, European University Institute, Florence. It is a professor at Faculty of Economics of Coimbra University. The main areas of interest are International Macroeconomics and Business Cycles.

Luís ALÇADA-ALMEIDA received the PhD in Management Sciences (Information Management) at the University of Coimbra. The main areas of research are: information systems analysis and algorithm development, multimedia systems, geographical information systems, databases and algorithm servers. 